\title{
THE EARLY SOCIAL SCIENCE OF W. E. B. DU BOIS
}

\author{
Robert W. Williams \\ Department of Political Science, Social Work, and Sociology, Bennett College
}

\begin{abstract}
Using the critical tools of social science, W. E. B. Du Bois challenged the White supremacism of his era. During the late nineteenth and early twentieth centuries, he presented his views on social inquiry in various programmatic pieces (e.g., "The Study of the Negro Problems" and "The Atlanta Conferences"), all the while conducting empirical research on the conditions and experiences of African Americans. This essay examines the ways in which Du Bois's programmatic statements were elaborated in his early works of social science, notably: his goal of scientific truth, the specificity of his research scope, and the research topics for investigation. Three of Du Bois's projects-The Philadelphia Negro; The Negroes of Farmville, Virginia; and the Atlanta University Publications-are detailed. In addition, this essay derives several insights from Du Bois that address issues common to debates in the philosophy of social science, such as the controversies over researcher neutrality and the rigor of politically engaged scholarship.
\end{abstract}

Keywords: Social Science, Research Methodology, Philosophy of Social Science, The Philadelphia Negro, The Negroes of Farmville, Virginia, Atlanta University Publications

\section{INTRODUCTION}

W. E. B. Du Bois (1868-1963) applied social science to the quest for racial and social justice within the United States. As his primary research goal, he sought to discover the "laws of social living" as they involved African Americans and their specific experiences (Du Bois 1968, p. 217). Du Bois held that scientifically derived knowledge about Blacks could challenge dominant (even White supremacist) views and could - and should-inform future public policies intended not only to improve African American lives, but also to realize America's democratic promise.

Specifically, this essay will relate Du Bois's programmatic statements from "The Study of the Negro Problems" (1898b), “The Atlanta Conferences" (1904a), and the unpublished "Sociology Hesitant" (1905) to three exemplary projects: The Philadelphia Negro (1899); The Negroes of Farmville, Virginia (one of Du Bois's studies com- 
missioned by the U.S. Bureau of Labor Statistics and published in 1898); and several of the Atlanta University Publications (AUP) which he supervised and (co-)edited in the early 1900s. I will assess the extent to which such works furthered the plan of his research program.

Many scholars have examined Du Bois's social science, analyzing his research in various ways. The intellectual influences on Du Bois's thought have been extensively studied, whether in terms of G. W. F. Hegel's philosophy, William James's pragmatism, or the German historical school of economics (Barkin 2000; Lemke 2000; Lewis 1993, 2000; Reed 1997; Taylor 2004; West 1989; Zamir 1995). Still others have inquired into specific Du Boisian works and their significance (Bay 1998; Gordon 2000; Moses 1993). While such scholars have framed the philosophical influences on and social contexts of Du Bois's research, less explored has been the connection of his early social-scientific works with his guiding research program.

Of relevance to this paper are several scholars who have identified a link between "The Study of the Negro Problems" (among other programmatic essays) and Du Bois's social science (Bracey et al., 1971; Jefferson 1996). In particular, Lucius Outlaw (2000) has examined the institutional context in which "The Study of the Negro Problems" was first presented and the scope of issues as they relate to the philosophy of social science. Nonetheless, despite the insights offered, virtually none of these authors has elaborated in detail how the ideas are prefigured in specific early social science works; a partial exception is Zuberi, in his analysis of The Philadelphia Negro (Zuberi 2004). Although he mentions that work as it pertained to "The Study of the Negro Problems," Zuberi does not elaborate on its relationship to "The Study."

In order to examine the mostly unexplored connections between Du Bois's programmatic essays and his early social-scientific works, the essay will unfold as follows. First, I wish to situate Du Bois's early social science within the larger intellectual context which informed his work. His significance for U.S. social science will be noted. I will outline briefly the use of social inquiry by Du Bois's predecessors, and I will also outline some of the prevailing views about African Americans which his studies sought to challenge. Then, I will delineate his research program in terms of goal, scope, and topics. Next will come a treatment of the three early socialscientific works, each with its individual importance and benefits specified. Finally, I will discuss the fact that Du Bois did not achieve his primary research goal. Although Du Bois uncovered much vital information to rebut the White supremacist thought of his era, he did not, by his own admission, formulate a set of social laws as they pertained to African Americans. Nonetheless, his efforts inspired other researchers and offer us a number of insights that are pertinent to contemporary discussions of social science practice.

\section{DU BOIS AND U.S. SOCIAL SCIENCE}

In his posthumously published Autobiography, W. E. B. Du Bois noted the mixed reception he received from scholars in the government and academic sectors of his day. His views and social-scientific works were often sought for congressional testimonies and U.S. Bureau of Labor Statistics reports, as well as for lectures in the United States and abroad (Du Bois 1968, Chapter XIII, pp. 220, 228), and several of his scholarly works were published in mainstream academic journals (Du Bois 1898b, 1908, 1918, 1944b). Moreover, a few academic textbooks acknowledged Du Bois's expertise on African American issues and referenced his research, e.g., Charles 
Ellwood's Sociology and Modern Social Problems (Ellwood 1910); Ernest R. Groves's An Introduction to Sociology (Groves 1928); and Thames Ross Williamson's Problems in American Democracy (Williamson 1922). In addition, Du Bois's The Philadelphia Negro was sometimes cited by other scholars (Elwang 1904; Thomas 1904). However, Du Bois also recalled in his autobiographical writings both professional and personal exclusion and indignities. In Dusk of Dawn, an interesting combination of autobiography and academic treatise on race, Du Bois explained, "where I studied, what I wrote and what I could get published—all this depended and depended primarily upon an overwhelming mass of my fellow citizens in the United States, from whose society I was largely excluded" (Du Bois 1940b, Chapter 6, p. 653). Du Bois was not considered, until recently, to be germinal to the development of sociology in the United States (Green and Driver, 1978; Zuckerman 2004). In Du Bois's words, "We rated merely as Negroes studying Negroes, and after all, what had Negroes to do with America or science?" (Du Bois 1968, Chapter XIII, p. 228).

Over time, Du Bois has become more accepted as one of the founders of American sociology (Marable 1986, p. 28; Marable 2004; Wortham 2005; Wright 2002a, 2002b, 2005). Many of Du Bois's works, including The Philadelphia Negro (1899) and The Negroes of Farmville, Virginia (1898a), have been heralded as pathbreaking works of social-scientific inquiry on African American conditions (Lewis 1993; Zuckerman 2004). Others have considered his social-scientific research to be pioneering in areas such as U.S. criminal justice (Gabbidon 1999), and the sociology of African American religion is treated in studies such as the Atlanta University Publication The Negro Church (Du Bois 1903a; Zuckerman 2002). Quite significantly, the American Sociological Association recognizes Du Bois's contributions in its Centennial Bibliography on the History of American Sociology (Hill 2005).

While there is merit in considering Du Bois as a pioneer of U.S. social science, it is important to underscore the existence of previous writings which likewise called into question the prevailing scholarship about African Americans, including Wilson Armistead's A Tribute for the Negro: Being a Vindication of the Moral, Intellectual, and Religious Capabilities of the Coloured Portion of Mankind (1848); Frederick Douglass's Claims of the Negro, Ethnologically Considered (1854); and George W. Williams's History of the Negro Race in America From 1619 to 1880 (1883). Other African American writers used "hard data" in their counterattacks against racism and prejudice (Young and Deskins, 2001). Consider, for example, Anna Julia Cooper's "What Are We Worth?" in her $A$ Voice from the South (1892); Alexander Crummell's "A Defense of the Negro Race in America" (1883); T. Thomas Fortune's Black and White: Land, Labor, and Politics in the South (1884); and Ida B. Wells-Barnett's antilynching works such as The Red Record (1895; see also Wells-Barnett 1892, 1900). While such writers did not typically conduct survey research or participant observation in established social-scientific ways, they did gather data using archival-style research in their efforts to counter charges leveled against African Americans. Of the need for the systematic and scientific study of African Americans, William Wells Brown wrote:

The colored people of the United States are sadly in need of a National Scientific Association, to which may be brought yearly reports of such investigations as may be achieved in science, philosophy, art, philology, ethnology, jurisprudence, metaphysics, and whatever may tend to unite the race in their moral, social, intellectual and physical improvement (Brown 1880, p. 252).

Thus, Du Bois was working within a tradition that sought to bring information about race problems to a broader audience in the United States and the world. 
An understanding of Du Bois's intellectual context in the late nineteenth century also requires us to note several other studies of specifically urban environments, specifically those conducted by Charles Booth, Jane Addams and Hull House, and Jacob Riis. Many scholars have noted that Du Bois was inspired by the research approach of Charles Booth in his monumental Life and Labour of the People of London, 9 Vols., a city-wide study of the distribution of poverty by geographic area and by occupations (Booth 1892-1897; Bay 1998; Broderick 1959; Gabbidon 1999; Lewis 1993, p. 190; Young and Deskins, 2001, p. 453). Indeed, Du Bois himself cited Booth in The Philadelphia Negro (Du Bois 1899, Section 28). Booth mostly utilized streetlevel data because of the difficulties of collecting information on and in a city as large as London. The contributors to the Hull-House Maps and Papers (Addams 1895) indicate that the model provided by Charles Booth was useful to their studies of Chicago, even though the surveys they conducted were limited to a particular area within Chicago (Addams 1912). Similarly, Du Bois, who was acquainted with other such city-wide studies as well, concentrated his investigations on areas smaller in scope: specifically, areas in which African Americans were heavily concentrated (Lewis 1993, p. 190; Broderick 1959).

While the Booth and Hull-House studies did include some tabulated and mapped data, another famous study of the late nineteenth century emphasized a more journalistic approach: Jacob Riis's How the Other Half Lives (1890). Riis utilized his personal experiences, coupled with compelling photographs, to investigate the conditions of the poorer areas of New York, including those of African Americans and East European immigrants, among others (Riis 1931). Du Bois, while not writing in a journalistic style, nevertheless was able to convey some sense of the flesh-andblood people whose experiences he studied. He often included verbatim survey responses in his published works.

Du Bois, while important in his own right as a social science pioneer, is also important because of how he furthered the goals of social justice championed by those who preceded him.

\section{DU BOIS'S RESEARCH PROGRAM}

With aspects of the relevant intellectual context in mind, let us turn to Du Bois's work, in particular. Du Bois was extensively educated in the social-scientific and historical techniques of the late nineteenth century, especially at Harvard and the University of Berlin (Du Bois 1968, Chapters IX and X; Barkin 2000; Gregg 1998; Lewis 1993, Chapters 5 and 6; Marable 1986, Chapter 2). For Du Bois, the quest for scientifically derived Truth-and he sometimes capitalized the word-was paramount. Reformers might use the data, but it had to be scrupulously gathered according to the tenets of the scientific method (Lemke 2000). After sketching several dominant and generally negative perspectives on African Americans, this section will outline Du Bois's research program as his effort to challenge such views.

In Du Bois's day we find many examples of academic and popular (mis-)conceptions about African Americans_-views which said little or nothing about equality between the races. African Americans, some asserted, were not capable of much if any progress, due to their supposedly innate inferiority, as exhibited by a range of behaviors and traits. According to many commentators, the so-called inherently negative traits were biological in origin. For ethnologist A. H. Keane, the imputed biological weaknesses were traceable to the physiological aspects of African brains (Keane 1896, pp. 44-46). Others used Darwinian-style interpretations. For example, 
Ellwood held that, as a result of natural selection, the African environment had influenced the development of humans who were allegedly "better adapted" for a torrid climate filled with comestible abundance (Ellwood 1910, Chapter X). Continuing in the tradition of "innate" differences, the intelligence quotient (IQ) numbers derived from intelligence testing were used to reinforce a commonly held view that Africans and African Americans were less intelligent than Whites (Brigham 1923; Terman 1916, pp. 91-92).

Other commentators argued that some mental and moral progress was possible, so long as African Americans maintained contact with Anglo-Saxons, such as had occurred (ostensibly) during the times of slavery. Without such interaction, however, there was little hope for African Americans in the future (Keane 1896, p. 268; Page 1892 , pp. 403, 410). Indeed, the subject of slavery had brought forth treatises hailing the putatively benign and educative consequences of slavery for slaves themselves. This view was certainly common in the antebellum South, as the book Sociology for the South by George Fitzhugh (1854) bore witness. But decades later the same view was still found, even among noted academic scholars. For example, in American Negro Slavery (1929), Ulrich Bonnell Phillips wrote:

The master was ruled by a sense of dignity, duty and moderation, and the slaves by a moral code of their own. This embraced a somewhat obsequious obedience, the avoidance of open indolence and vice, the attainment of moderate skill in industry, and the cultivation of the master's good will and affection.... In general the relations on both sides were felt to be based on pleasurable responsibility (Phillips 1929, Chapter XVI, pp. 328-329).

Du Bois did not hesitate to address and rebut such arguments (Du Bois 1918; Fredrickson 1971).

The allegedly negative traits of African Americans were often expressed in discussions over practical matters, including politics, business, and crime. The so-called inferiority of African Americans had policy implications. For example, commentators held that Blacks exhibited an unfitness for the vote and an inability to elect good political leaders. Thomas Nelson Page, a devoted southerner, wrote about what he considered to be the corruption of African Americans in state governmental offices during Reconstruction (Page 1892; Dunning 1907). For other commentators, the industriousness of African Americans had languished since slavery had ended (Straton 1900, p. 793) — a view which, for Nathaniel Southgate Shaler, indicated that Blacks were not able to form business partnerships, nor to coordinate activities (Shaler 1884, p. 701). Crime was a major concern for many discussants in the popular and academic presses. For example, Cesare Lombroso, a founder of positivistoriented criminal anthropology, observed increases in homicide by African Americans (and also immigrants). He suggested that removing African Americans and immigrants would correct the high rate of homicides in the United States (Lombroso 1897 , pp. 647-648).

Given such (mis-) conceptions, Du Bois held that the extant "knowledge base" about African Americans was inadequate, even suspect. Accordingly, Du Bois's socialscientific mission became to uncover the conditions and experiences of African American lives. Du Bois was well suited for this important task. In the words of one of his contemporaries, Benjamin Brawley:

There had been sound scholars in the race before DuBois, but generally these had rested on attainment in the languages or mathematics, and most frequently 


\section{Robert W. Williams}

they had expressed themselves in rather philosophical disquisition. Here, however, was a thorough student of economics, and one who was able to attack the problems of his people and meet opponents on the basis of modern science. He was destined to do great good, and the race was proud of him (Brawley 1921, pp. 307-308).

Through his research program, Du Bois would seek to challenge the hegemonic views on race and African Americans in the United States. I will sketch the program in terms of his research goal, the temporal and spatial scope of research, and his research topics.

Du Bois had no use for grand theories purporting to explain human civilization, including those theories which had already "decided" that Africans and those of African descent could only occupy a subordinate social role (Du Bois 1905). In a 1904 essay, “The Atlanta Conferences,” Du Bois wrote:

It is certain that we cannot at once compass all human action in time and eternity - the field is too vast and much valuable time has already been wasted in trying to do the impossible under the brilliant but questionable leadership of Herbert Spencer. We must more and more school ourselves to the minute study of limited fields of human action, where observation and accurate measurement are possible and where real illuminating knowledge can be had. The careful exhaustive study of the isolated group [i.e., African Americans] then is the ideal of the sociologist of the 20th Century-from that may come a real knowledge of natural law as locally manifest-a glimpse and revelation of rhythm beyond this little center [at Atlanta University] and at last careful, cautious generalization and formulation (Du Bois 1904a, p. 54).

In other words, Du Bois's primary research goal was ultimately to delineate socialscientific "laws" via a process of tentative generalizations from data gathered over time. In the aftermath of debates in the latter part of the twentieth century, social science has been characterized by a commitment to the idea that lawlike regularities constitute our (provisional) knowledge of any given subject area. Nonetheless, both Du Bois and later social scientists sought explanations for the patterns or uniformities observed in the data collected, an aim reiterated in Du Bois's 1968 autobiography. Referring to the long-term implications of the Atlanta University Studies, he wrote: "I hoped to make the laws of social living clearer, surer, and more definite" (Du Bois 1968, Chapter XIII, p. 217).

Although there has been much debate in the social sciences over whether humans and societies can be studied like rocks, atoms, or animals (Smith 1997), many thinkers have sought social laws analogous to the laws of the natural sciences. In the late nineteenth century, scientific laws of the natural sciences were often characterized as deterministic or, to use Windelband's term, nomothetic (Windelband 1980). Under Condition Alpha we would expect Cause $S$ (or even Causes $T$ and $U$ ) to result in Outcome Beta. Even in the twentieth century when probabilistic statements became more common, Outcome Beta would be stated in terms of a likelihood of X percent. Regardless of whether we convey social-scientific explanations in the language of strict determinism or that of probabilities, such quantitative frameworks generally accord little or no theoretical importance to the conscious will of human agency and the meaningfulness of social actions to the individuals themselves.

Yet the search for the laws of social living has not precluded a nondeterministic view ascribing an influential role for chance and human will in social actions. Fur- 
thermore, as Du Bois wrote in "Sociology Hesitant," "behind Chance [sic] we place free human wills capable of undetermined choices" (Du Bois 1905, p. 43). In Du Bois's words:

Looking over the world, we see evidence of the reign of Law; as we rise, however, from the physical to the human there comes [sic] not simply complication and interaction of forces but traces of indeterminate force until in the realm of higher human action we have Chance-that is actions undetermined by and independent of actions gone before. The duty of science, then, is to measure carefully the limits of this Chance in human conduct (Du Bois 1905, p. 44).

As we shall see, understanding the importance of chance/free will to the early Du Bois will help us to better comprehend his later reaction, under conditions of severe racial oppression, to the difficulties he perceived when he adhered to the tenets of mainstream social science research.

In Du Bois's “The Study of the Negro Problems” (SNP) (Du Bois 1898b), we discover how his research program was designed to achieve the primary goal of truth manifested in scientific laws (Lewis 1993, pp. 193-194). Published in 1898, the paper was originally presented as a speech for the forty-fourth meeting of the American Academy of Political and Social Science held in Philadelphia in November 1897 (Du Bois 1968, pp. 199-202; Gordon 2000; Outlaw 2000). In SNP, Du Bois proposed to tackle, through social-scientific inquiries, the challenges posed by the White supremacist arguments (my term) prevalent in the nineteenth century. In order to better understand how such social phenomena might be studied, I will delineate several aspects of Du Bois's research program.

While Du Bois often reiterated the importance of individual responsibility, he also sought explanations of African Americans' actions in the contexts of their everyday lives. Such explanations were not framed in terms of some innate biological factor, but rather in terms of their contingent social circumstances, both the present conditions and also historically influential ones (Taylor 1981). For Du Bois, a truly scientific study of racial issues would investigate the underlying factors that had caused social differences to emerge among African Americans, as well as between African Americans and Whites.

In $S N P$ Du Bois indicated that both temporal and spatial variations needed to be studied in order to fully grasp African American lives and circumstances (Du Bois 1898b). His sensitivity to temporal and spatial dimensions allows us to delineate the scope of his research program: he advocated the study of African Americans in particular communities with regard to the change (or not) of variables over time, and the similarities or differences of those variables across space, whether in individual locales/communities, larger geographical entities such as states or regions, or the country as a whole. It must be added, however, that Du Bois did perform some research that transcended localized geographic units. For example, in the Atlanta University studies of college-educated African Americans (Du Bois 1900, 1910), survey research on Black college graduates from all around the United States was conducted.

Du Bois set forth "two categories of study": "(a) the study of the Negro as a social group, [and] (b) the study of his peculiar social environment"-specifically the conditioning environment of racial prejudice (Du Bois 1898b, p. 81). He indicated that, although the two categories were interrelated and difficult to separate, they needed to be kept analytically distinct in order to gain a "logical clearness" about "Negro problems" (Du Bois 1898b, p. 81). Both categories could be part of the same 
project, but he stressed that distinctions had to be maintained. In this case, Du Bois was attempting to identify first who African Americans were and what demographic characteristics they manifested. How and why their particular conditions arose was a related, but analytically different, issue. Only after knowing about Black demographics would one be able to discern the possible reasons for the observed characteristics.

Based on the categories and the scope of the $S N P$, at least three chief research topics can be outlined. First, Du Bois's studies would assess the extent to which African Americans as a population were relatively homogeneous in terms of variables such as education, occupation, wealth, and so forth. As a corollary topic, Du Bois often compared similarities and differences between African Americans and other nationalities in foreign countries. Second, his research would examine indicators of social progress (e.g., educational attainment, jobs, property holdings, etc.) in order to ascertain whether the conditions and situations of African Americans had changed over time and in particular places. Third, Du Bois's studies would analyze the larger societal environments for factors (economic, racial, etc.) that conditioned, positively and negatively, life chances for Blacks. All of this information would be used to challenge the White supremacist idea of African Americans being constrained by immutable biological characteristics, in addition to forming the basis for more specific questions and hypotheses.

In order to investigate these research topics, Du Bois employed what today is called research triangulation (Wortham 2005; Wright 2002a, 2005). Du Bois utilized multiple tools, especially interviews, archival research, and field observations, in order to reduce the errors that might occur if only one methodology were employed. Du Bois explicitly elaborated this methodological pluralism in The Philadelphia Negro (Du Bois 1899, Sections 2, 3). In addition, Du Bois himself often included the questionnaires used in his research within his texts (for example, in The Philadelphia Negro and in various Atlanta University Publications) making it possible to replicate the studies over time.

The following sections will illustrate Du Bois's research program by outlining three early social-scientific writings of Du Bois: The Philadelphia Negro; The Negroes of Farmville, Virginia: A Social Study; and several typical AUPs.

\section{THE PHILADELPHIA NEGRO}

The growth of industrialization and urbanization in the United States, especially in the latter part of the nineteenth century, had generated not only wealth and everyday conveniences, but also poverty and social problems. During the Progressive Era, various actors and institutions in both private and public sectors sought to ameliorate the conditions of the disadvantaged (Schafer 2001). Yet some Progressive Era reformers viewed the socially disadvantaged paternalistically, maintaining that the poor and downtrodden lacked the cultural qualities necessary for social success. Accordingly, they typically advocated programs to cultivate higher morality.

To advance the Progressive Era ideals and goals, Du Bois was hired to conduct in-depth research on the African American residents of the Seventh Ward of Philadelphia (Lewis 1993, pp. 188-189). Although the Seventh Ward had a majority population of Whites, it also was home to the largest number of Blacks in the city (Du Bois 1899, Section 14). A member of Philadelphia's wealthy and influential Wharton family, Susan Wharton, persuaded the University of Pennsylvania to commission a study of the city's African Americans. The head of the university's Department of Sociology, Samuel McCune Lindsay, hired Du Bois to carry out the research. 
Although Du Bois suspected that there were politically partisan motives behind the research project, he did not let this deter him (Du Bois 1968). In 1896, he and his wife moved from Wilberforce College (where he had been a professor) to Philadelphia's Seventh Ward.

Although The Souls of Black Folk (Du Bois 1903b) would become his most well-known work, the book that resulted from this Philadelphia research was to become a pathbreaking study of urban African American sociology. At least two previous studies in the form of data compilations on African American occupations, crime, and literacy had been conducted in Philadelphia prior to the U.S. Civil War (Bacon 1859; Society of Friends 1849). However, when The Philadelphia Negro was published in 1899, Du Bois provided the first detailed social-scientific analysis of a Black urban community (Lewis 1993, p. 190). The book also contained data on African American churches in Philadelphia-the first such urban-based research conducted (Baer 1998; Zuckerman 2002). In addition, the book well exemplified the use of multiple methodologies: Du Bois employed door-to-door surveys, archival data gathered from public sources, and participant observation of the African American residents of the Seventh Ward. Du Bois included the survey instruments or schedules, as he called them, as a set of appendices to the book.

Du Bois himself considered The Philadelphia Negro to be important both for what it had uncovered about the city's Seventh Ward African Americans, and for how it directly challenged the White supremacist thinking of his day. The research "revealed the Negro group as a symptom, not a cause; as a striving, palpitating group, and not an inert, sick body of crime; as a long historic development and not a transient occurrence" (Du Bois 1968, Chapter XII, pp. 198-199). Du Bois's research identified class differences in terms of income, education, and jobs-findings which ran counter to the dominant American views that Blacks were homogeneously poor, criminal, uneducated, and unsuccessful (Du Bois 1899, Section 22, p. 100; Section 46, pp. 309 311). Du Bois's findings also called into question statements which minimized racial prejudice and discrimination. For example, noted author and Mark Twain collaborator Charles Dudley Warner (1829-1900) had written:

Wherever a negro [sic] has shown himself able, honest, attentive to the moral and economic duties of a citizen, either successful in accumulating property or filling honorably his station in life, he has gained respect and consideration in the community in which he is known; and this is as true at the South as at the North (Warner 1902, p. 217).

Du Bois argued against such views by detailing how, in a climate of racial enmity, African Americans suffered regardless of their positive personal qualities. He also charged that Philadelphia more generally faced decreased prosperity when the most educated and best skilled of the African Americans were not hired as a result of racial prejudice (Du Bois 1899, Section 58, p. 394).

The Philadelphia Negro (TPN) has at least three significant facets. First, its conceptual framework promoted an understanding of race and class within the economic system of the city, thereby attacking the biological arguments of Black inferiority. Second, TPN mentioned the idea of the "Talented Tenth" for the first time. African American elites would become a much-discussed motif in Du Bois's strategies for social change. Third, TPN based its suggestions for change on data collection and interpretation-promoting a partnership between (social) science and public policy. 
In the first regard, as Lewis has commented, Du Bois set forth a conceptual framework of race, social class, and economics (Lewis 1993, p. 208) in order to explain why African Americans experienced problems in a specific place, Philadelphia. Du Bois delineated differences among Blacks based on class status, including occupation, income, property holdings, educational attainment, and so forth. He indicated that the economic situation was precarious for "upper-class" Blacks-the legal, religious, and medical professionals, as well as business entrepreneurs-due to the uncertainty of being able to attract enough patrons (Du Bois 1899, Section 46, pp. 317-319). Working-class African Americans likewise faced tough competition in labor markets for jobs in trades, manual labor, and domestic service (Du Bois 1899, Section 23, p. 139). The racial prejudice experienced by all classes of African Americans exacerbated any other difficulties encountered (Bobo 2000).

Differences in class among African Americans arose partly, Du Bois argued, because the upper classes could thrive in a tough capitalist economy as a result of their value system, which included a work ethic, moral restraint, and the importance of personal incentive. Despite the racism that obstructed Black elites from even higher achievements, the successful ones were prosperous because they had assimilated the "appropriate" value system needed for success. Thus, for Du Bois, the social-class distinctions among Seventh Ward Blacks emerged in part because some had the knowledge and the moral fiber to take advantage of economic circumstances which might arise within a racially restricted city environment [cf. Bay (1998) and Zuberi (2004), who have commented on Du Bois's cultural argument, which underpinned his view of the relative success of Black professionals in Philadelphia].

The Philadelphia Negro presented Du Bois's formulation of an overall dynamic to explain the condition of African Americans in the city. It used empirical methods to connect personal behaviors, attitudes, and worldviews to a specific socioeconomic context and to a larger historical trajectory. Du Bois specified behaviors and attitudes which were not conducive of a productive lifestyle and good work habits, such as diminished personal motivation and moral laxity (Du Bois 1899, Section 57, pp. 390393). But he argued that such behaviors and attitudes were the result of the legacy of slavery (Du Bois 1899, Section 21, p. 97; Section 24, p. 145; Section 39, p. 249; Section 43, p. 284) and the prevailing racial discrimination in employment and business (Du Bois 1899, Section 23, p. 134; Section 43, p. 284; Section 47, pp. 350351; Section 58, p. 395). To varying degrees and for different reasons, diverse writers of the era agreed with Du Bois's view on the deleterious legacy of slavery for the work ethics of African Americans, including Booker T. Washington (1896, pp. 326-327), sociologist Charles A. Ellwood (1910), and author Charles Dudley Warner (1902).

The second significant facet of The Philadelphia Negro (TPN) was its introduction of Du Bois's claim regarding the importance of a Black elite for racial advance (Lewis 1993, p. 209), an idea given fuller elaboration in a later essay, "The Talented Tenth" (Du Bois 1903c). In TPN, Du Bois provided details of Black professionals and entrepreneurs (Du Bois 1899, Section 22, p. 100; Section 46, p. 311)-those whom Du Bois called the "best classes" or the "aristocrats" of African Americans (Du Bois 1899, Section 46, pp. 316-318). He indicated that those elites were separate and "distanced" from the average Black Philadelphian because they wished to distinguish themselves from the others, they had different value systems, and they had already expended much time and energy coping with the uncertainties of the economy. Despite this distance, Du Bois suggested that successful Black professionals and entrepreneurs should do more to assist, in his words, the "lowest classes."

The third significant facet of The Philadelphia Negro highlighted how Du Bois was a pioneer in the tradition of using social science to inform public policy. 
Du Bois offered suggestions for racial uplift and for improving social conditions. $\mathrm{Du}$ Bois penned a last chapter with suggestions-duties, as he termed them-for solving the city's race problems. African Americans were to promote and cultivate socially and economically "proper" behavior and attitudes. Whites were encouraged to remove racial barriers that hindered Blacks from advancing as far as their skills and interests would allow them. This facet of TPN resonates with the work of many contemporary social scientists and public administrators whose work separates data collection and analysis from its use in public policy.

One final remark should be made about Du Bois's terminology in The Philadelphia Negro. Du Bois argued against the injection of personal biases into research (Du Bois 1899, Section 3, p. 3), a point underscored by perusing the schedules, or survey instruments, which he used in his research, as well as the schedules used to describe conditions via participant observation (Du Bois 1899, Appendix A). The schedules were scrupulously neutral in tone. Nevertheless, the Victorian-style language employed by Du Bois in describing the data in terms of "best" and "worst" classes reflected some of the ways in which mainstream social science, and residual glimmers of Herbert Spencer's idea of the "survival of the fittest," had also influenced Du Bois (Bay 1998; Rampersad 1990). We can perhaps say that, while Du Bois's data collection upheld a more neutral stance, his descriptions of the data were often cast in more subjective terms of social hierarchy rather than in an objective set of operational definitions.

The Philadelphia Negro was a major social-scientific project, but it was only one of a number of significant achievements through which Du Bois reinvigorated social science in the United States on the cusp of a new millennium.

\section{THE NEGROES OF FARMVILLE, VIRGINIA: A SOCIAL STUDY}

In the late nineteenth century, the U.S. Bureau of Labor Statistics began to commission studies of African American communities. Supervised by Carroll Wright, the Bureau sponsored nine studies from 1897 to 1903 (Grossman 1974; Lewis 1993, pp. 194-197; U.S. Department of Labor n.d.). While still working on his Philadelphia project, Du Bois decided to avail himself of the opportunity presented by the Bureau. He visited Farmville, Virginia, during July and August of 1897, taking a two-month hiatus from Philadelphia in order to do research in the South. Du Bois studied African Americans in Farmville and its environs, including the nearby and predominantly Black community of Israel Hill. His research involved the methods already employed in Philadelphia: door-to-door interviews of African Americans, participant observation, and archival studies of public records (Lewis 1993, p. 195). The demographic variables collected were like those used in the Philadelphia project, including employment and wages, marriages and divorces, property holdings, and family expenses. The final report became The Negroes of Farmville, Virginia: A Social Study (NFVA) (Du Bois 1898a).

The importance of the Farmville project lies in its observation and analysis of increasing class differentiation within a Black community (Lewis 1993). Because the work was published in 1898, prior to TPN's publication in 1899, the Farmville study bears the distinction of being the first of Du Bois's social science works to challenge the homogeneity thesis, according to which African Americans were relatively similar, in sociological terms. The NFVA project focused on increasing urbanization and industrialization, as well as their concomitant implications for Blacks (Du Bois 1898a, p. 38). 


\section{Robert W. Williams}

By investigating the quality of everyday life using demographic data gathered via surveys and participant observation, Du Bois offered a synchronic snapshot of a particular locality. Yet he broadened that focus with a comparative angle, providing data from the United States more broadly, as well as from Italy, Ireland, Hungary, Great Britain, Germany, and France. Those data invited readers to compare Blacks in Farmville with other population groups in the same area and nation, as well as in foreign lands. In addition, Du Bois's use of archival records from the Prince Edward County Clerk's Office uncovered indications of progress, or lack thereof, in property holdings (Du Bois 1898a, pp. 4, 6). Although the study reads like a technical treatise, the NFVA offered readers a new perspective on an African American community, one founded on data rather than the derogatory stereotypes so frequent in the news and popular culture of the day (Dixon 1902).

When comparing the African Americans in Farmville to the United States as a whole, Du Bois noted both similarities and differences. For example, using data from the 1890 U.S. Census, Du Bois showed that, relative to national averages, more Blacks in Farmville held jobs in manufacturing (mainly tobacco processing) and in domestic services than in agriculture (Du Bois 1898a, pp. 16, 19, 21). Differences aside, Du Bois stressed that there were indications that the city's African Americans had progressed in ways which accorded with conventional White American standards. Regarding the Black entrepreneurs of Farmville, he wrote: "The individual undertaker of business enterprise is a new figure among Negroes, and his rise deserves to be carefully watched, as it means much for the future of the race" (Du Bois 1898a, p. 17). With this and several other examples, Du Bois would find some agreement with Booker T. Washington, who maintained that personal responsibility and the provision of useful products and services, supported by industrial training, would help African Americans to gain the respect of Whites (Washington 1899, p. $355 ; 1901$, pp. 202-203).

As in TPN, Du Bois pointed out in NFVA the positive aspects of the African American community he studied, but he did not shirk from noting where the community needed, in his view, improvement. He used data to support both his positive and his negative assessments, again, often cast in the Victorian language of the time. So, for example, Du Bois wrote:

It seems fair to conclude, after an impartial study of Farmville conditions, that the industrious and property accumulating class of the Negro citizens best represents, on the whole, the general tendencies of the group. At the same time, the mass of sloth and immorality is still large and threatening (Du Bois 1898a, p. 38).

The NFVA report offered its White and Black audience the data needed to formulate socially beneficial policies to assist a specific community.

As in TPN, Du Bois also identified in the NFVA report individual behaviors within a larger sociohistorical context. For example, Du Bois accounted for part of the negative effects on morals in terms of an economic factor. The irregular jobs typically found in the region's tobacco and manufacturing sectors generated idleness, which, he suggested, led to the opportunity for immorality (Du Bois 1898a, p. 22). It should also be noted that Du Bois mentioned racial discrimination once with regard to the wages of mechanics in Farmville (Du Bois 1898a, p. 20). In addition, Du Bois briefly recounted the history of Israel Hill: the community had arisen on the land of an old plantation given to emancipated slaves upon the death of their master. In 
short, ongoing and explicit racism did not seem to be an explanatory factor accounting for the experiences reported in NFVA.

The Farmville study highlighted an interesting facet of social science research: the problem of how to interpret the data gathered. Du Bois argued that the Farmville data revealed a social tendency toward class-based differences. Yet he also indicated how one's assumptions about African Americans (especially any supposedly innate, biological characteristics) could influence the interpretation of the data:

A study of a community like Farmville brings to light facts favorable and unfavorable, and conditions good, bad, and indifferent. Just how the whole should be interpreted is perhaps doubtful. . . For instance, a visitor might tell us that the Negroes of Farmville are idle, unreliable, careless with their earnings, and lewd; another visitor, a month later, might say that Farmville Negroes are industrious, owners of property, and slowly but steadily advancing in education and morals. These apparently contradictory statements made continually of Negro groups all over the land are both true to a degree, and become mischievous and misleading only when stated without reservation as true of a whole community, when they are in reality true only of certain classes in the community. The question then becomes, not whether the Negro is lazy and criminal, or industrious and ambitious, but rather what, in a given community, is the proportion of lazy to industrious Negroes, of paupers to property holders, and what is the tendency of development in these classes. . . .

How far Farmville conditions are true elsewhere in Virginia the present investigator has no means of determining. He sought by inquiry and general study to choose a town which should in large degree typify the condition of the Virginia Negro to-day. How far Farmville fulfills this wish can only be determined by further study (Du Bois 1898a, p. 38).

As his text explains, Du Bois offered a way to social scientifically evaluate-and potentially to dispute-the often negative views found in mainstream White American discourse. Sufficient amounts of data must be gathered through various methods and the data must relate to valid demographic variables (e.g., occupations, education, criminal records, etc.) that make it possible to test bypotheses (e.g., "Is there progress or regress as measured by changes in the variables over time?"). Hence, the appropriate data must be gathered before generalizations can be drawn-a trenchant criticism of "car-window sociologists," as he called them in The Souls of Black Folk (Du Bois 1903b, Chapter VIII). Moreover, for Du Bois, social tendencies can be speculated upon, provided that the speculations are based on the data and that more studies are encouraged (Du Bois 1898b).

A few more studies were conducted by Du Bois (and others), and later published by U.S. government agencies (Du Bois 1980; U.S. Department of Labor n.d.). Other Du Boisian empirical projects were soon to materialize, as we shall see in the case of the AUPs.

\section{THE ATLANTA UNIVERSITY PUBLICATIONS}

Du Bois's skills in social science were becoming more widely known by the late 1890s. While finishing up the research phase in Philadelphia (and with his contract 
at the University of Pennsylvania soon ending), Du Bois was asked to come to Atlanta University to teach (Lewis 1993, pp. 194, 198). In 1898, Du Bois also assumed leadership of the Atlanta University conferences (Lewis 1993, pp. 217-225). Those conferences had already produced two works under the guidance of George C. Bradford, who had initially proposed the annual events. In AUP No. 1, Mortality among Negroes in Cities, Bradford had used surveys and examined various types of census data (Chase 1903, pp. 7-10). Following Du Bois's direction, the Atlanta University conferences would do still more to promote social science. Such an approach would add data to the often moral tone and admonitions which characterized much of the work on African Americans and their stories of improvement. Especially common in books and compendiums of the era were uplifting stories of the personal successes of African Americans, as well as their businesses and religious organizations (Brown 1863; Carter 1894; Haley 1895; Richings 1902).

Not surprisingly, we find that Du Bois's research program as articulated in "The Study of the Negro Problems" (1898b) also was pursued in the AUPs that arose out of the annual conferences. In the preface to a volume on Morals and Manners among Negro Americans, of which Du Bois was a co-editor, the Conference goals were clearly expressed:

There is only one sure basis of social reform and that is Truth-a careful, detailed knowledge of the essential facts of each social problem. Without this there is no logical starting place for reform and uplift. Social difficulties may be clear and we may inveigh against them, but the causes proximate and remote are seldom clear to the casual observer and usually are quite hidden from the man who suffers from, or is sensitive to, the results of the snarl. . .

This study is an attempt to collect opinion on the general subject of morals and manners among Negro Americans from those who ought to know. It is by no means complete or definitive, but it is to some degree enlightening. . . .

The study is, therefore, a further carrying out of the plan of social study of the Negro American, by means of an annual series of decennially recurring subjects covering, so far as is practicable, every phase of human life. This plan originated at Atlanta University in 1896. The object of these studies is primarily scientific-a careful research for truth.... Our object is not simply to serve science. We wish not only to make the truth clear but to present it in such shape as will encourage and help social reform (Du Bois and Dill, 1913, pp. 5-6).

Other volumes of the Atlanta University studies typically included some variant of this statement.

As the initial director of the Atlanta University conferences, Bradford had sought to conduct "scientific studies of social problems" to be addressed: "In regard to the conferences: It is proposed each year to take up the discussion of certain phases of city life most deserving attention. Just what will be the subjects for these discussions will be determined by the results of investigations already begun, and announcements will be made later" (Bradford 1903, p. 10). Although his plans were similar to Bradford's, Du Bois's academic training was evidenced in his more explicit advocacy of the primary goal of social science inquiry: the generation of knowledge in the form of the "laws of social living."

In order to gain scientific knowledge of African Americans, Du Bois employed the inductive approach in which he had been schooled during his graduate years. In his final autobiography he wrote: 
What I was laboriously but steadily approaching in this effort was a recurring cycle of ten studies in succeeding decades; with repetition of each subject or some modification of it in each decade, upon a progressively broader and more exact basis and with better method; until gradually a foundation of carefully ascertained fact would build a basis of knowledge, broad and sound enough to be called scientific in the best sense of that term (Du Bois 1968, p. 216).

Gaining knowledge involved a slow and methodical process, but one on which Du Bois was willing to expend much energy. The AUPs were intended to be the implementation of such a plan.

The Atlanta University conferences made a substantial contribution to developing an increasingly systematic understanding of African American lives and experiences (Gabbidon 1999; Rudwick 1957; Wright 2002a, 2005). The AUPs can be assessed in terms of three benefits. First, they typically researched important topics within particular localized geographical areas (e.g., cities and states, especially Georgia). However, some studies, for example, The College-Bred Negro (Du Bois 1900) and The Negro Common School (Du Bois 1901), spanned the country. In The College-Bred Negro, survey research was conducted on all of the Black college graduates in the United States who could be contacted. Although not specific to a particular spatially delimited community, this study allowed Du Bois to tackle mainstream White concerns about the consequences of higher education for African Americans (Du Bois 1904a, p. 59). Were Black colleges graduating too many students? Were such graduates educated in useless skills, making it difficult for them to find available jobs? The survey results indicated that the majority of Black college graduates were, in fact, employed, and in a range of useful professions (Du Bois 1900, pp. 37, 63, 72). The data uncovered thus challenged some dominant (mis-)perceptions about African Americans.

Another important social issue tackled by Du Bois in the AUPs was crime. In the study Notes on Negro Crime Particularly in Georgia (Du Bois 1904b), crime statistics were gathered from several large U.S. cities and the State of Georgia. A central concern of the study was disputing conventional claims that crime was increasing among African Americans, in general, and among educated African Americans, in particular (Du Bois 1904b, pp. 9-10). Editor Du Bois, as well as others, including Monroe N. Work and H. H. Proctor, directly challenged such claims by amassing descriptive statistics and providing methodological critiques of the reasoning behind the mainstream assertions. The study found a somewhat decreasing general rate of crime and stressed the association of the decreasing crime rate in Georgia with the increase in African American educational attainment and property holdings (Du Bois 1904b, pp. 32, 64).

A second benefit of the Atlanta University conferences is that the reports offered the basis for future research. The studies provided data that could be used to evaluate any possible development over time in the geographic areas under study. This is of course what Du Bois had indicated in the Farmville study was necessary: diachronic analyses of African Americans and their life chances and social conditions. Two criticisms of the AUPs have been made in this context. While many of the questions used on the surveys remained the same in volumes pertaining to the same topic, subsequent surveys sometimes expanded the details solicited from the respondents. Rudwick argued that this made it more difficult to compare the subject matter diachronically (Rudwick 1957, p. 472). In addition, questionnaire response rates, now a standard part of research, were not reported (Rudwick 1957). 


\section{Robert W. Williams}

A third benefit from the Atlanta University studies was the large amount of first-person data often provided (Du Bois and Dill, 1913). Such responses derived from surveys used in the project, the questions of which the AUPs typically included in the text. Although anecdotal and self-reported, and hence not directly verifiable (Broderick 1959, pp. 41-42), such data can make the statistical averages, as presented by the AUPs, more fully human. Years earlier, in The Philadelphia Negro, Du Bois had already recorded anecdotal accounts as a way to supplement the archival and participant-observation modes of inquiry (Du Bois 1899, Section 47). In addition, the first-person passages could help in the generation of future research hypotheses, used in what today is called qualitative data analysis.

Du Bois's plan for longitudinal studies was not to be achieved during his long lifetime. Several factors intervened. The Atlanta University conferences confronted limited financial support, as is clear from the repeated requests for more funding in the prefaces of the different volumes. Du Bois believed that he had become too controversial, especially due to his public disagreements with Booker T. Washington. As a consequence, the Atlanta University conferences faced increasing difficulty in attracting more financial resources. In his 1968 autobiography, Du Bois wrote:

Gradually I began to realize that the difficulty about support for my work in Atlanta University was largely personal; that on account of my attitude toward Mr. Washington I had become persona non grata to powerful interests, and that Atlanta University would not be able to get support for its general work or for its study of the Negro problem so long as I remained at the institution. No one ever said this to me openly, but I sensed it in the worries which encompassed the new young President Edmund Ware who had succeeded Dr. Horace Bumstead. I began to realize that I would better look out for work elsewhere (Du Bois 1968, Chapter XIV, p. 252).

In addition, Du Bois's own desire to engage in activism led him to assume the editorship of The Crisis, the flagship periodical of the newly formed NAACP, in 1910 (Lewis 1993, p. 386).

The Atlanta conferences ultimately ended, as did their annually published publications (Lewis 1993, pp. 379, 383). Although occupied with many other civil rights projects, Du Bois retained a desire to use carefully crafted social science (Du Bois 1940a). In the 1940s, Du Bois proposed a research project to several land-grant colleges that was similar to, and understood to be a continuation of, the previous Atlanta University studies (Du Bois 1968, Chapter XVIII, pp. 309ff). Although endorsed by the participating land-grant colleges, the project produced only a few publications (e.g., Du Bois 1943) because of funding shortages (Du Bois 1968, Chapter XVIII, pp. 324-325).

\section{DISCUSSION}

Du Bois pursued an energetic research agenda, as evidenced in "The Study of the Negro Problems" and "The Atlanta Conferences." Du Bois's early social science projects embodied his view that the discovery of truth in the form of social laws was to be the primary goal, and it would be attained ultimately through adherence to the rigorous scientific method. By using science as a tool, hegemonic beliefs about Blacks could be disputed social scientifically, and public policies could be crafted to effect social reform. 
Various dimensions of Du Bois's research program were fulfilled by the early social-scientific works examined in this paper. The intent to address particularity in time and place-the research scope-was exemplified by The Philadelphia Negro; The Negroes of Farmoille, Virginia; and in the Atlanta University Publications. As regards the research topics, the studies addressed the issue of homogeneity in terms of differences observed in indicators of wealth, jobs, education, and property. The studies documented some degree of progress operationalized in terms of an increase in the amount of specific demographic indicators. The studies also analyzed the broader societal environment for factors which conditioned, both positively and negatively, the life chances of Blacks. Economics was a major factor for Blacks in the NFVA, while economics coupled with racism influenced the lives analyzed in TPN. Various Atlanta University studies found both economic and racial influences, depending on the issue being investigated.

Du Bois used descriptive statistics, often presenting the data in the form of tables or graphs. He did not use the inferential statistics which had been developed in the nineteenth century (Smith 1997). With regard to qualitative methods, Du Bois emphasized, in varying ways and degrees, that the voices of those studied should be permitted to speak in his social-scientific treatises. The personal quotations provided glimpses of the people behind the numbers, illustrating his view of the importance of studying particular places and communities.

However, the overarching research goal of deriving the "laws of social living" was not specifically met by Du Bois or in his empirical works. He did not uncover social laws akin to the physical laws of gravity or thermodynamics. Significantly, the longitudinal aspect of the research scope was not achieved according to the plans set by Du Bois himself. Neither the decades-spanning agenda of the Atlanta University studies nor the project through the land-grant colleges proposed in the 1940s was realized. Commenting on the long-term time frame of the Atlanta University project and its goal of discerning "the laws of social living," Du Bois wrote:

Some of this was accomplished, but of course only an approximation of the idea. For 13 years we poured forth a series of studies; limited, incomplete, only partially conclusive, and yet so much better done than any other attempt of the sort in the nation that they gained attention throughout the world (Du Bois 1968, p. 217).

Not enough studies were conducted to provide the basis for the social science laws which Du Bois had hoped to uncover. Nonetheless, Du Bois had offered (provisional) conclusions regarding African American progress when the data warranted such interpretations (Rudwick 1957).

What can we learn about social science from Du Bois's long-term, albeit incomplete, research project? To address this question, we can examine several dimensions of the philosophy of social science from the perspective of Du Bois's contributions to social inquiry. In his 1944 essay "My Evolving Program for Negro Freedom," Du Bois raised questions about (deterministic) social-scientific laws, just as he had done in his unpublished "Sociology Hesitant" essay four decades before. Regarding his earlier social-scientific works, he asked: "For what Law was I searching? In accord with what unchangeable scientific law of action was the world of interracial discord about me working?" (Du Bois 1944a, pp. 57-58). While he certainly did not abandon a quest for scientific knowledge, over time Du Bois appeared to reorient the relationship between research and activism/practice (Jefferson 1996). That Du Bois did not personally discover the laws of social living should not be interpreted to mean 


\section{Robert W. Williams}

that he considered social science itself to be a failure. Rather, there was a change in his understanding of the role of social science in relation to society at large and to its potential to mediate social change. In particular, we can discern several insights that arise from Du Bois's developing practice of social science, which I shall examine in turn: (a) the importance of specificity in the research program, (b) the research agenda and its topics of inquiry, (c) the neutrality of the researcher, (d) the rigor of engaged scholarship, and (e) the pursuit of truth via engaged research.

\section{Specificity}

The first insight involves the relationship between the specific and the general within the research agenda. As part of his overall research program, Du Bois sought the specificity of particular places: What were the demographic characteristics of African Americans, and under which social conditions did they live and work? Despite individual limitations, The Philadelphia Negro, The Negroes of Farmville, Virginia, and the AUPs are exemplars that can still inspire today. While affirming the importance of specific places in his research projects, Du Bois did not avoid larger, even global, sociohistorical processes. Within the early social-scientific studies, Du Bois situated the particular communities within larger-scale historical processes (involving, e.g., racism or economic relationships) that conditioned the people whose lives he studied. Moreover, in numerous later works, Du Bois situated information gained from studies of specific places (conducted by him or others) within broader processes, especially colonialism and the general expansion of capitalism around the globe. Typical books treating global processes included The Negro (1915), Black Folk, Then and Now (1939), and The World and Africa (1947). Hence, as an insight gleaned from $\mathrm{Du}$ Bois, we can say that "grand" theories devoid of the painstaking studies of particular places would be too abstract and thus irrelevant to a social-scientific inquiry into the state of African Americans (Du Bois 1944a).

Reinforcing Du Bois's perspective on specificity is the case of American environmental injustice. Environmental justice activists and researchers argue that poorer communities (often communities of color) are disproportionately located near pollution and waste sites. Much debate has occurred over the merits of analyses that are solely or chiefly based on aggregate data (Williams 1999, 2005). Different conclusions have been reached on the prevalence (or not) of environmental injustice. Often lost amidst such debates is the specificity of particular communities and their embeddedness within the larger social relationships of capitalism and ethnic/racial discrimination. In order to better understand why and how any given community might have come to bear such burdens, some contemporary researchers have argued in favor of local analyses that seek to identify the sociohistorical processes occasioning the conjunction of particular communities and pollution (Pulido 1996; Pulido et al., 1996).

\section{Research Agenda}

Turning to the second insight, the importance of studying the specificity of groups and social conditions leads to the research agenda. What are the issues that can be-indeed, should be-studied? For Du Bois, a normative question was paramount throughout his life: What concerns and variables should be researched for the sake of the group, community, or country? Du Bois's trope of the color line provided researchers with at least some of the basic sets of issues to study. The separation of the races and the consequences of segregation and discrimination became salient issues to 
investigate (Du Bois 1903b). Thus, although Du Bois did not directly state it this way, a research agenda is not neutral. Certain issues are more important for security and progress than are others. Over time, issues of gender and class increasingly became a part of Du Bois's own research agenda.

While particular issues changed over time, Du Bois's social-scientific work sought to discover the signs of economic, political, and social progress. As reported in various publications, Du Bois discerned much evidence of this progress. Nowadays, the debate is not usually over whether African American progress is possible (although this remains an issue for blatant White supremacists), but over the extent of any remaining discrimination, as well as the possible causes and solutions. Currently, controversies swirl in various areas. Through statutory and constitutional measures, as well as legal remedies, some argue that the de jure discrimination of Jim Crow, poll taxes, and literacy tests, has been addressed. However, others argue that de facto discrimination still blights America, especially institutionalized racism and its effects experienced as disproportionate burdens by persons of color in areas such as health care, education, and economic opportunity (Karpati and Frieden, 2004).

In addition, controversies still continue over the causes of and possible solutions to African American problems. Recent debates have often included cultural explanations for any perceived lack of social progress. This debate pits, for example, comedian and philanthropist Bill Cosby against scholar and professor Michael Eric Dyson. For Cosby, it is not racism per se that undermines the success of some African Americans, but certain culturally based beliefs and irresponsible actions (PBS 2004). Dyson, by contrast, argues that African American behavior is a response to persistent racist and exploitative social contexts (PBS 2005). Du Bois would recognize the contours of this particular debate.

\section{Neutrality}

A third insight emerges from Du Bois's personal confrontation with his early social science. It involves the issue of the neutrality of the researcher-a topic much debated in the philosophy of social science (Gouldner 1973; Nagel 1979; Weber 1949). Researcher neutrality is viewed as important for there to be any credibility to the whole process of social inquiry and its suggested prescriptions for public policy. A lack of neutrality is conceived in terms of the particular interests of an individual researcher or research team clouding the research process itself (e.g., in selectively gathering data or in drawing certain conclusions without considering seriously the merits of rival explanations).

Many in the mainstream social sciences today would argue that complete disinterest is humanly impossible. Nevertheless, some semblance of researcher neutrality can be achieved to the extent that established scientific procedures are followed. Furthermore, neutrality in the research process can be enhanced to the extent that researchers both divulge conflicts of financial or personal interest and also present the data and research methods employed so as to allow for review, critique, and replication by others, presumably with different interests (Babbie 1992).

Numerous critics, however, argue that even quasineutrality is not possible. For example, Michel Foucault argued that our ideas, beliefs, and theories-discoursesare permeated by power relations arising from specific historical contexts and social institutions. Such discourses structure the very objects of inquiry and constrain the presumed universality of an observer (Foucault 1970). For Donna Haraway, social science presumes a singular "God's-eye" view perched above the objects of inquiry and hence supposedly unobstructed by biases. She argues that individual humans, 


\section{Robert W. Williams}

including researchers, are an embodied multiplicity of identities and responsibilities. To choose one perspective as the sole basis for knowledge denies not only our selves and our responsibilities in life, but also the multiple ways that reality is experienced as meaningful by others (Haraway 1991). Thus, some social theorists have held that even the self-disclosure of interests and the adherence to research protocols do not address the limited and limiting perspectives of conventional research.

Studying Du Bois allows us to understand his contributions to the debate over the (presumed) neutrality of the researcher. A Du Boisian stance on the issue of neutrality would emphasize his statements on the embodiment of the researcher in the community or group that s/he is studying. Because he was African American and faced similar experiences of racial prejudice and discrimination to those he researched, Du Bois himself was not only involved personally but also committed morally. Recollecting his time during the Atlanta University conferences, Du Bois wrote in "My Evolving Program for Negro Freedom":

I began to know the problem of Negroes in the United States as a present startling reality; and moreover (and this was most upsetting) I faced situations that called-shrieked-for action, even before any detailed, scientific study could possibly be prepared. It was as though, as a bridge-builder, I was compelled to throw a bridge across a stream without waiting for the careful mathematical testing of materials. Such testing was indispensable, but it had to be done so often in the midst of building or even after construction, and not in the calm and leisure long before. I saw before me a problem that could not and would not await the last word of science, but demanded immediate action to prevent social death. I was continually the surgeon probing blindly, yet with what knowledge and skill I could muster, for unknown ill, bound to be fatal if I hesitated, but possibly effective, if I persisted.

I realized that evidently the social scientist could not sit apart and study in vacuo; neither on the other hand, could he work fast and furiously simply by intuition and emotion, without seeking in the midst of action, the ordered knowledge which research and tireless observation might give him. I tried therefore in my new work, not to pause, when remedy was needed; on the other hand I sought to make each incident and item in my program of social uplift, part of a wider and vaster structure of real scientific knowledge of the race problem in America (Du Bois 1944a, p. 57).

One can say that, for Du Bois, researchers-especially those from oppressed groupsare not disinterested and therefore cannot be neutral in the conventional sense sought in science (further nuances are discussed below with regard to the fourth and fifth insights).

In his later research, Du Bois abandoned notions of an absolutely neutral researcher standing above the fray; instead, researchers were a part of the communities of color being studied. Du Bois wrote quite succinctly about the predicament faced by him and arguably by other scholars of color. Of the personal effect upon him of Sam Hose's lynching in Atlanta in 1899 (Dray 2003), Du Bois explained, "one could not be a calm, cool, and detached scientist while Negroes were lynched, murdered and starved" (Du Bois 1968, Chapter XIII, p. 222; Du Bois 1940b, Chapter 4, p. 603). Lynch mobs and all-White southern juries of the era would probably not distinguish the African American researcher from anyone else in the African American community. Hence, researchers were socially engaged; indeed, their social embodiment in the communities being studied was implied in their inextricable engagement. 


\section{Rigor}

A fourth insight from Du Bois arises from the question of whether this engagement and not-fully-neutral dimension of African American researchers means that there is less scientific rigor in their studies. In early works like The Philadelphia Negro, Du Bois was concerned that personal bias might distort the research insofar as proper procedures were not scrupulously followed (Du Bois 1899, Section 3). However, as time passed, and Du Bois continued to experience the enduring social oppression in the United States, he took a more radical stance on politics (Lewis 1993, 2000). His perspectives and activism can inform a discussion of what scientific rigor means in social-scientific research. Specifically, scientific rigor need not be compromised as a result of the social engagement of the researcher.

Across his life span, Du Bois collected and advocated the further collection of the same types of data as in his early social science work. We can read of this in his 1940s proposal for a social science project to be conducted by several land-grant colleges (Du Bois 1968, Chapter XVIII). In later works, including his 1953 essay "Negroes and the Crisis of Capitalism in the United States," Du Bois utilized demographic data similar to what he had collected decades earlier in The Philadelphia Negro and The Negroes of Farmville, Virginia. Yet, in the later pieces, his socialist-leaning values came to the forefront, and the interpretive conclusions diverged from those of the earlier works. As he stated in an essay inaugurating the academic journal Phylon in 1940, the publication would use an economic interpretation in order to understand the significance of the data gathered by empirical studies (Du Bois 1940a).

Conventional social-scientific methodologies can be employed, complete with their ideas of validity and reliability, and thereby contribute to the rigor of a research project. But, for Du Bois, data did not "speak for themselves." Because multiple meanings are possible, scholars cannot simply discern the significance of phenomena by observing them (Northrop 1959). A theory or other interpretive framework is necessary in order to understand the meaning and social significance of the phenomena. For the later Du Bois, the interpretation of the data (usually collected by conventional social-scientific means) was informed by more radical theories of oppression. In short, Du Bois accepted that the separation of data collection from data interpretation was important. However, such a separation could both more strongly ensure the rigor of the data collection process and also allow him to interpret the phenomena according to their significance for social change and betterment.

\section{Truth}

A related, and fifth, insight emerges here. Social engagement does not necessarily imply that one abandons the quest for truth_or what today might be called the scientific knowledge of probabilistically delineated regularities in the phenomena. For the later Du Bois, the social engagement of the researchers meant that they were in a different (practical) relationship with the objects of inquiry from that which was conventionally accepted by mainstream social science.

Those holding that social engagement tends to bias research conclusions also usually consider that the relationship between the knower and the known must be kept as separate as possible. This is referred to as the subject/object problematic: what is to be known must not be "contaminated" by the knowers (researchers). Contamination would mean that the known would be altered or changed from what it truly was. A failure to follow the proper research protocols would mean that the data gathered would not yield the correct knowledge of the object of study; this is a standard principle taught in social science training. This position was also Du Bois's view in 


\section{Robert W. Williams}

The Philadelphia Negro (Du Bois 1899, Section 2, 3). In subsequent decades, debates in the philosophy of social science would offer both support and criticism of the separation of knower and the known (Collins 1991, Chapter 11).

As explained by the later Du Bois, the rationale for social engagement came from the vital need to fight White supremacism immediately. Such activities, however, had to be informed by knowledge acquired through quantitative and historiographical methods. The social engagement advocated by the later Du Bois should not be understood in terms of a separate, "non-influencing" relationship between knower and known. This knower/known relationship, as conceived by Du Bois, required a different philosophical basis from that of the mainstream social science of the early twentieth century. Du Bois's awareness that he could not stand aloof from society thus led him back to the works and inspiration of several Harvard professors, among them pragmatist William James. As Du Bois wrote in 1944:

I fell back upon my Royce and James and deserted Schmoller and Weber. I saw the action of physical law in the actions of men; but I saw more than that: I saw rhythms and tendencies; coincidences and probabilities; and I saw that, which for want of any other word, I must in accord with the strict tenets of Science, call Chance. I went forward to build a sociology, which I conceived of as the attempt to measure the element of Chance in human conduct. This was the Jamesian pragmatism, applied not simply to ethics, but to all human action, beyond what seemed to me, increasingly, the distinct limits of physical law (Du Bois 1944a, p. 58).

For Du Bois, the pragmatism of William James would allow for the researcher to take a stand in the world as a being who was also an integral participant in that world. Humans are neither solely subject/knower nor object/known, but rather are inseparably connected as both subject and object. Humans act in the world and evaluate the effectiveness of the activities for achieving the desired goals.

In his 1968 autobiography, Du Bois provided a further glimpse into his longstated acknowledgment of the necessity to study "the element of Chance in human conduct." Regarding the unfunded research plans of the 1940s, Du Bois expressed regrets that the project did not go forward:

On such a base a real science of sociology could have been built. The opportunity was surrendered and the whole science of sociology has suffered. I even had projected a path of scientific approach: I was going to plot out beside the world of physical law, a science of sociology which measured "the limits of chance in human action." If this field proved narrow or nonexistent, world law was proven. If not, the resultant "chance" was what men had always regarded as "free will" (Du Bois 1968, p. 324).

In his early social science, Du Bois had tended to cast the idea of free will in voluntaristic terms; for example, in The Philadelphia Negro he held that, once African Americans were freed from discrimination, their embrace of middle-class cultural values would enhance their professional and financial success. The later, more radical Du Bois framed the role of free will differently. Within a capitalist society, free will (and its corollary of hard work) was no guarantee of financial success or of a just distribution of resources, products, and services; the economic system tended to favor those better placed within the status quo class structure. The later Du Bois 
believed that free will(s) oriented toward social justice would only be actualized by human agency struggling within and against oppressive and exploitative structures.

The research/activism nexus had implications for the philosophy undergirding Du Bois's social science, especially his later views. The ostensibly "truthful" statements embodied in research conclusions are not static and indeed cannot be static. Truth is a provisional inference from observations that are informed by our theoretical understanding of casual processes. As William James wrote: "The truth of an idea is not a stagnant property inherent in it. Truth happens to an idea. It becomes true, is made true by events. Its verity is in fact an event, a process: the process namely of its verifying itself" ( James 1907, Lecture VI, p. 201). Building from James's perspective, Du Bois's activities implied that social scientifically informed activism (practice) was a mediating element between reality and conceptions of that reality. Researchers and the knowledge they generated were thereby part of the production of the truthfulness of our concepts of reality. Instead of being a disinterested party, the researchers of racial injustice would scientifically seek knowledge of particular circumstances in space and time and then provide the analyses needed to fight White supremacism and to struggle against those conditions and structures oppressing African Americans.

Here we see the pragmatism of William James overlapping somewhat provocatively with a Marxist-inspired concept of praxis (Avineri 1968). Du Bois had been a student of James while at Harvard University, but he became an appreciative reader of Marx after the Russian Revolution (Du Bois 1968, Chapter XVII). Du Bois, thus inspired by both James and Marx, believed and theorized that social reality itself could be changed, albeit within certain limits. But those limits did not preordain a demeaning and lower status for Blacks worldwide, as White supremacists proclaimed. Ultimately, the conclusions arrived at by engaged researchers were integrally part of the quest for knowledge and truth-especially the quest for what was deemed to be the truth at one time and place and under certain conditions. As regards racism and its consequences, what researchers learned about, for example, an observed group's levels of educational attainment or economic success was not the truth for all time. It did not have to be that way. The findings of such researchers would factor into efforts to change the conditions leading to negative outcomes, while also reinforcing those policies that provided opportunities for positive growth and development.

Such are the insights offered by Du Bois through his personal confrontation with his early social science. In the whirl of unfolding events in time and space, Du Bois modified elements of his social science research process. Yet he did not change his view on the importance of social science in the quest for social justice.

\section{CLOSING REMARKS}

The rationale for Du Bois's research was to combat injustice through social science and to open to critical scrutiny a range of questions which some believed had already been answered. In that quest, he succeeded. Although in later life Du Bois did not continue his extensive social-scientific work, others in the twentieth century have built on Du Bois's legacy, even while taking it in new directions: Richard R. Wright, Jr. (1903, 1912), George E. Haynes (1912), Monroe N. Work (1931), George R. Arthur (1934), Charles S. Johnson (1938), E. Franklin Frazier (1932, 1939, 1957), St. Clair Drake and Horace Cayton (1945), Oliver C. Cox (1948), William Julius Wilson (1980), and Antonio McDaniel (1998), among others (Young and Deskins, 2001). 


\section{Robert W. Williams}

Colleges, universities, and think tanks have regularly tackled important issues for persons of color in the United States through institutes, centers, and departments of Africana or Black Studies. Of note, the Du Bois Institute at Clark Atlanta University has recommenced annual conferences on topics relevant to African Americans (Du Bois Institute n.d.). The research and activism for social justice thus have continued into the new millennium. Du Bois's lasting importance, then, is not to be found merely in the vast body of his research and writing. More significantly, his legacy emerges from the ways in which his abiding purpose and deep commitments have inspired so many others to struggle against injustice and to work together for a more egalitarian world.

Corresponding author: Dr. Robert W. Williams, Department of Political Science, Social Work and Sociology, Bennett College, 900 East Washington Street, Greensboro, NC 27401. E-mail: rwilliams@ bennett.edu

\section{REFERENCES}

Addams, Jane (1895). Hull-House Maps and Papers: A Presentation of Nationalities and Wages in a Congested District of Chicago. New York: T. Y. Crowell. 〈http://www2.pfeiffer.edu/ lridener/ DSS/Addams/hhtoc.html $\rangle$ (accessed October 10, 2006).

Addams, Jane (1912). Twenty Years at Hull House. New York: Macmillan. 〈http://digital. library.upenn.edu/women/addams/hullhouse/hullhouse.html> (accessed October 10, 2006).

Armistead, Wilson (1848). A Tribute for the Negro: Being a Vindication of the Moral, Intellectual, and Religious Capabilities of the Coloured Portion of Mankind; with Particular Reference to the African Race. Manchester, UK: William Irwin. 〈http://docsouth.unc.edu/armistead/ armistead.html (accessed October 10, 2006).

Arthur, George R. (1934). Life on the Negro Frontier. New York: Association Press.

Avineri, Shlomo (1968). The Social and Political Thought of Karl Marx. London, UK: Cambridge University Press.

Babbie, Earl (1992). The Practice of Social Research, 2ed. Belmont, CA: Wadsworth.

Bacon, Benjamin C. (1859). Statistics of the Colored People of Philadelphia. Taken by Benjamin C. Bacon, and pub. by order of the Board of education of "The Pennsylvania society for promoting the abolition of slavery," etc., $2 \mathrm{~d}$ ed. Philadelphia, PA: Pennsylvania Society for Promoting the Abolition of Slavery, Board of Education. 〈http://hdl.loc.gov/loc.rbc/lcrbmrp.t1620〉 (accessed October 10, 2006).

Baer, Hans A. (1998). Du Bois, William Edward Burghardt. In William H. Swatos, Jr., et al. (Eds.), Encyclopedia of Religion and Society. Walnut Creek, CA: AltaMira Press. 〈http:// hirr.hartsem.edu/ency/dubois.htm $\rangle$ (accessed October 10, 2006).

Barkin, Kenneth (2000). "Berlin Days," 1892-1894: W. E. B. Du Bois and German Political Economy. boundary 2, 27(3): 79-101.

Bay, Mia (1998). "The World was Thinking Wrong about Race": The Philadelphia Negro and Nineteenth-Century Science. In Michael Katz and Thomas Sugrue (Eds.), W. E. B. Du Bois, Race, and the City: The Philadelphia Negro and Its Legacy, pp. 41-60. Philadelphia, PA: University of Pennsylvania Press.

Bobo, Lawrence (2000). Reclaiming a Du Boisian Perspective on Racial Attitudes. Annals of the American Academy of Political and Social Science, 568: 186-202.

Booth, Charles (1892-1897). Life and Labour of the People of London, 9 Vols. London, UK: Macmillan and Company. Some of the data and maps are available at: Charles Booth Online Archive 〈http://booth.lse.ac.uk/〉 (accessed October 27, 2006); Charles Booth's 1889 Descriptive Map of London Poverty 〈http://www.umich.edu/ risotto/〉 (accessed October 27, 2006); Charles Booth Notebooks by Caroline Ferris /http://www.fathom.com/feature/ 122154/> (accessed October 27, 2006).

Bracey, John, August Meier, and Elliott Rudwick (1971). The Black Sociologists: The First Half Century. Belmont, CA: Wadsworth Publishing.

Bradford, George G. (1903). Occasion and Purpose of the Conference, and an Outline of the 
Plan of Work. In Thomas N. Chase (Ed.), Mortality Among Negroes in Cities, 2ed., abridged, Atlantic University Publication (AUP) No. 1, pp. 7-11. Atlanta, GA: Atlanta University Press. 〈http://fax.libs.uga.edu/E185x5xA881p/1f/atlanta_univ_pub_no_01.pdf $\rangle$ (accessed October 10, 2006).

Brawley, Benjamin (1921). A Social History of the American Negro, Being a History of the Negro Problem in the United States Including a History and Study of the Republic of Liberia. New York: Macmillan Company. 〈http://www.gutenberg.org/etext/12101〉 (accessed October 10, 2006).

Brigham, Carl C. (1923). A Study of American Intelligence. Princeton, NJ: Princeton University Press.

Broderick, Francis L. (1959). W. E. B. Du Bois: Negro Leader in a Time Of Crisis. Stanford, CA: Stanford University Press.

Brown, William Wells (1863). The Black Man, His Antecedents, His Genius, and His Achievements. New York: Thomas Hamilton. 〈http://docsouth.unc.edu/brownww/menu.html〉 (accessed October 10, 2006).

Brown, William Wells (1880). My Southern Home, or The South and Its People. Boston, MA: A. G. Brown and Company. 〈http://docsouth.unc.edu/neh/brown80/menu.html〉 (accessed October 10, 2006).

Carter, Edward Randolph (1894). The Black Side: A Partial History of the Business, Religious and Educational Side of the Negro in Atlanta, Ga. Atlanta, GA: [s. n.]. 〈http://fax.libs.uga.edu/ E185x93xG4xC323/> (accessed October 10, 2006).

Chase, Thomas N. (Ed.) (1903). Mortality Among Negroes in Cities, 2ed., abridged, Atlantic University Publication (AUP) No. 1. Atlanta, GA: Atlanta University Press. 〈http:// fax.libs.uga.edu/E185x5xA881p/1f/atlanta_univ_pub_no_01.pdf $>$ (accessed October 10, 2006).

Collins, Patricia Hill (1991). Black Feminist Thought: Knowledge, Consciousness, and the Politics of Empowerment. New York: Routledge.

Cooper, Anna Julia (1892). A Voice from the South. Xenia, Ohio: Aldine Printing House. $\langle$ http://docsouth.unc.edu/church/cooper/cooper.html (accessed October 10, 2006).

Cox, Oliver Cromwell (1948). Caste, Class, and Race: A Study in Social Dynamics. New York: Doubleday and Company.

Crummell, Alexander (1883). A Defence of the Negro Race in America from the Assaults and Charges of Rev 7. L. Tucker, D.D., of Fackson, Miss., in His Paper Before the "Church Congress" of 1882, on "The Relations of the Church to the Colored Race." Washington, DC: Judd and Detweiler. 〈http://hdl.loc.gov/loc.rbc/lcrbmrp.t0e01〉 (accessed October 10, 2006).

Dixon, Thomas (1902). The Leopard's Spots: A Romance of the White Man's Burden-1865-1900. New York: Doubleday, Page and Company. 〈http://docsouth.unc.edu/dixonleopard/ menu.html $\rangle$ (accessed October 10, 2006).

Douglass, Frederick (1854). The Claims of the Negro, Ethnologically Considered: An Address before the Literary Societies of Western Reserve College, at Commencement, Fuly 12, 1854. Rochester, NY: Press of Lee, Mann and Company. 〈http://memory.loc.gov/cgi-bin/query/r?ammem/ rbaapc:@field(DOCID+@lit(rbaapc07900)) (accessed October 10, 2006).

Drake, St. Clair and Horace R. Cayton (1945). Black Metropolis: A Study of Negro Life in a Northern City. New York: Harcourt, Brace and Company.

Dray, Philip (2003). At the Hands of Persons Unknown: The Lynching of Black America. New York: Random House.

Du Bois, W. E. B. (1898a). The Negroes of Farmville, Virginia: A Social Study. Department of Labor, 14(January): 1-38. Washington, DC: U.S. Government Printing Office. 〈http:// etext.lib.virginia.edu/toc/modeng/public/DubFarm.html $>$ (accessed October 10, 2006).

Du Bois, W. E. B. (1898b [1978]). The Study of the Negro Problems. In Daniel Green and Edwin Driver (Eds.), W. E. B. Du Bois: On Sociology and the Black Community, pp. 70-84. Chicago, IL: University of Chicago Press.

Du Bois, W. E. B. (1899 [1996]). The Philadelphia Negro: A Social Study. Philadelphia, PA: University of Pennsylvania Press.

Du Bois, W. E. B. (Ed.) (1900). The College-Bred Negro, Atlantic University Publication (AUP) No. 5. Atlanta, GA: Atlanta University Press. 〈http://fax.libs.uga.edu/E185x5xA881p/1f/ atlanta_univ_pub_no_05.pdf $\rangle$ (accessed October 10, 2006).

Du Bois, W. E. B. (Ed.) (1901). The Negro Common School, Atlantic University Publication (AUP) No. 6. Atlanta, GA: Atlanta University Press. 〈http://fax.libs.uga.edu/E185x5xA881p/ 1f/atlanta_univ_pub_no_06.pdf $\rangle$ (accessed October 10, 2006).

Du Bois, W. E. B. (Ed.) (1903a). The Negro Church, Atlantic University Publication (AUP) No. 8. Atlanta, GA: Atlanta University Press. 〈http://docsouth.unc.edu/church/negrochurch/ menu.html (accessed October 10, 2006). 
Du Bois, W. E. B. (1903b). The Souls of Black Folk. Chicago, IL: A. C. McClurg and Company. 〈http://docsouth.unc.edu/church/duboissouls/menu.html〉 (accessed October 10, 2006).

Du Bois, W. E. B. (1903c). The Talented Tenth. In Booker T. Washington et al., The Negro Problem: A Series of Articles by Representative American Negroes of To-day, Chapter 2. New York: James Pott and Company. 〈http://www.gutenberg.org/etext/15041〉 (accessed October 10, 2006).

Du Bois, W. E. B. (1904a [1978]). The Atlanta Conferences. In Daniel Green and Edwin Driver (Eds.), W. E. B. Du Bois on Sociology and the Black Community, pp. 53-60. Chicago, IL: University of Chicago Press.

Du Bois, W. E. B. (Ed.) (1904b.) Notes on Negro Crime, Particularly in Georgia, Atlantic University Publication (AUP) No. 9. Atlanta, GA: Atlanta University Press. 〈http:// fax.libs.uga.edu/E185x5xA881p/1f/atlanta_univ_pub_no_09.pdf $\rangle$ (accessed October 10, 2006).

Du Bois, W. E. B. (1905 [2000]). Sociology Hesitant. boundary 2, 27 (3): 37-44.

Du Bois, W. E. B. (1908 [1970]). Is Race Separation Practicable? In Philip S. Foner (Ed.), W. E. B. Du Bois Speaks: Speeches and Addresses, 1890-1919, pp. 179-186. New York: Pathfinder Press.

Du Bois, W. E. B. (Ed.) (1910). The College-bred Negro American, Atlantic University Publication (AUP) No. 15. Atlanta, GA: Atlanta University Press. 〈http://fax.libs.uga.edu/ E185x5xA881p/1f/atlanta_univ_pub_no_15.pdf $\rangle$ (accessed October 10, 2006).

Du Bois, W. E. B. (1915). The Negro. New York: Henry Holt and Company. 〈http:// www.gutenberg.org/etext/15359) (accessed October 10, 2006).

Du Bois, W. E. B. (1918). Review of American Negro Slavery: A Survey of the Supply, Employment and Control of Negro Labor as Determined by the Plantation Regime by Ulrich Bonnell Phillips. American Political Science Review, 12 (November): 722-726.

Du Bois, W. E. B. (1939). Black Folk, Then and Now: An Essay in the History and Sociology of the Negro Race. New York: Henry Holt and Company.

Du Bois, W. E. B. (1940a [1995]). Apology. In David L. Lewis (Ed.), W. E. B. Du Bois: A Reader, pp. 215-217. New York: H. Holt and Company.

Du Bois, W. E. B. (1940b [1986]). Dusk of Dawn: An Essay Toward an Autobiography of a Race Concept. New York: Harcourt, Brace and Company. In Nathan Huggins (Ed.), W .E. B. Du Bois: Writings, pp. 549-802. New York: Library of America.

Du Bois, W. E. B. (Ed.) (1943). Report of the First Conference of Negro Land-Granting Colleges for Coordinating a Program of Social Studies, Atlantic University Publication (AUP) No. 22. Atlanta, GA: Atlanta University Press.

Du Bois, W. E. B. (1944a). My Evolving Program for Negro Freedom. In Rayford W. Logan (Ed.), What the Negro Wants, pp. 31-70. Chapel Hill, NC: University of North Carolina Press.

Du Bois, W. E. B. (1944b [1978]). Prospect of the World without Race Conflict. In Daniel Green and Edwin Driver (Eds.), W. E. B. Du Bois on Sociology and the Black Community, pp. 290-302. Chicago, IL: University of Chicago Press.

Du Bois, W. E. B. (1947). The World and Africa: An Inquiry into the Part which Africa Has Played in World History. New York: Viking.

Du Bois, W. E. B. (1953). Negroes and the Crisis of Capitalism in the United States. Monthly Review, April. 〈http://www.monthlyreview.org/0403dubois.htm〉 (accessed October 10, 2006).

Du Bois, W. E. B. (1968). The Autobiography of W. E. B. Du Bois: A Soliloquy on Viewing My Life from the Last Decade of Its First Century. New York: International Publishers.

Du Bois, W. E. B. (1980). Contributions by W. E. B. Du Bois in Government Publications and Proceedings. Edited by Herbert Aptheker. Millwood, NY: Kraus-Thomson Organization.

Du Bois, W. E. B. and Augustus Granville Dill (Eds.) (1913). Morals and Manners among Negro Americans, Atlantic University Publication (AUP) No. 18. Atlanta, GA: Atlanta University Press. 〈http://fax.libs.uga.edu/E185x5xA881p/1f/atlanta_univ_pub_no_18.pdf〉 (accessed October 10, 2006) or $\langle$ http://docsouth.unc.edu/church/morals/menu.html $\rangle$ (accessed October 10, 2006).

Du Bois Institute (Southern Center for Studies in Public Policy, Clark Atlanta University) (n.d.). History of Policy Center-CAU. 〈http://www.scspp.org/history.htm〉 (accessed January 2, 2007).

Dunning, William Archibald (1907). Reconstruction, Political and Economic, 1865-1877. New York: Harper and Brothers Publishers.

Ellwood, Charles A. (1910). Sociology and Modern Social Problems. New York: American Book Company. 〈http://www.gutenberg.org/dirs/etext04/sclgm10.txt (accessed October 10, 2006). 
Elwang, William Wilson (1904). The Negroes of Columbia Missouri: A Concrete Study of the Race. Masters Thesis, University of Missouri-Columbia, Department of Sociology. $\langle$ http://digital.library.umsystem.edu/cgi-bin/Ebind2h3?umc7〉 (accessed October 10, 2006).

Fitzhugh, George (1854). Sociology for the South, or, The Failure of Free Society. Richmond, VA: A. Morris. 〈http://docsouth.unc.edu/fitzhughsoc/menu.html〉 (accessed October 10, 2006).

Fortune, Timothy Thomas (1884). Black and White: Land, Labor, and Politics in the South. New York: Fords, Howard, and Hubert.

Foucault, Michel (1970). The Order of Things: An Archaeology of the Human Sciences. New York: Vintage Books.

Frazier, Edward Franklin (1932). The Negro Family in Chicago. Chicago, IL: University of Chicago Press.

Frazier, Edward Franklin (1939). The Negro Family in the United States. Chicago, IL: University of Chicago Press.

Frazier, Edward Franklin (1957). Black Bourgeoisie. New York: Collier Books.

Fredrickson, George M. (1971). The Black Image in the White Mind: The Debate on AfroAmerican Character and Destiny, 1817-1914. New York: Harper and Row.

Gabbidon, Shaun L. (1999). W. E. B. Du Bois and the "Atlanta school" of Social Scientific Research, 1897-1913. Fournal of Criminal fustice Education, 10(1): 21-38.

Gordon, Lewis R. (2000). Du Bois's Humanistic Philosophy of Human Sciences. Annals of the American Academy of Political and Social Science, (568): 265-280.

Gouldner, Alvin (1973). Anti-Minotaur: The Myth of a Value-Free Sociology. In Alvin Gouldner, For Sociology: Renewal and Critique in Sociology Today, pp. 3-26. London, UK: Allen Lane.

Green, Dan S. and Edwin D. Driver (Eds.) (1978). W. E. B. Du Bois on Sociology and the Black Community. Chicago, IL: University of Chicago Press.

Gregg, Robert (1998). Giant Steps: W. E. B. Du Bois and the Historical Enterprise. In Michael Katz and Thomas Sugrue (Eds.), W. E. B. Du Bois, Race, and the City: The Philadelphia Negro and Its Legacy, pp. 77-100. Philadelphia, PA: University of Pennsylvania Press.

Grossman, Jonathan (1974). Black Studies in the Department of Labor, 1897-1907. Montbly Labor Review, 97(6): 17-27. Available at /http://www.dol.gov/oasam/programs/history/ blackstudiestext.htm $\rangle$ (accessed October 10, 2006).

Groves, Ernest R. (1928). An Introduction to Sociology. New York: Longmans, Green and Company.

Haley, James T. (1895). Afro-American Encyclopaedia; or, The Thoughts, Doings, and Sayings of the Race. Nashville, TN: Haley and Florida. 〈http://docsouth.unc.edu/church/haley/haley.html〉 (accessed October 10, 2006).

Haraway, Donna (1991). Situated Knowledge: The Science Question in Feminism and the Privilege of Partial Perspective. In Donna Haraway, Simians, Cyborgs, and Women: The Reinvention of Nature. New York: Routledge.

Haynes, George E. (1912). The Negro at Work in New York City: A Study in Economic Progress. New York: Columbia University.

Hill, Michael. (2005). Centennial Bibliography on the History of American Sociology. Washington, DC: American Sociological Association.

James, William (1907). Pragmatism: A New Name for Some Old Ways of Thinking. London: Longmans, Green, and Company.

Jefferson, Paul (1996). Present at the Creation: Rethinking Du Bois's "Practice Theory". In Dennis Rutledge (Ed.), Research in Race and Ethnic Relations, Volume 9: W. E. B. Du Bois: The Scholar as Activist. Greenwich, CT: JAI Press.

Johnson, Charles S. (1938). The Negro College Graduate. Chapel Hill, NC: University of North Carolina Press.

Karpati, Adam M. and Thomas R. Frieden (2004). Health Disparities in New York City. New York: New York City Department of Health and Mental Hygiene. 〈http://www.nyc.gov/ html/doh/downloads/pdf/epi/disparities-2004.pdf (accessed October 11, 2006).

Keane, Augustus Henry (1896). Ethnology In Two Parts: I. Fundamental Ethnical Problems, II. The Primary Ethnical Groups. Cambridge, UK: University Press.

Lemke, Sieglinde (2000). Berlin and Boundaries: Sollen versus Geschehen. boundary 2, 27 (3): $45-78$.

Lewis, David Levering (1993). W. E. B. Du Bois: Biography of a Race, 1868-1919. New York: Henry Holt and Company.

Lewis, David Levering (2000). W. E. B. Du Bois: The Fight for Equality and the American Century 1919-1963. New York: Henry Holt and Company. 


\section{Robert W. Williams}

Lombroso, Cesare (1897). Why Homicide has Increased in the United States, Part I. The North American Review, 165 (493): 641-649. 〈http://cdl.library.cornell.edu/cgi-bin/moa/moacgi? notisid=ABQ7578-0165-66 (accessed October 10, 2006).

Marable, Manning (1986). W. E. B. Du Bois: Black Radical Democrat. Boston, MA: Twayne.

Marable, Manning (2004). The Leadership of Du Bois. Madison Times Weekly Newspaper, 13 (48). 〈http://www.madtimes.com/archives/dec2004_1/opinion2.htm〉 (accessed October 10, 2006).

McDaniel, Antonio (1998). The "Philadelphia Negro" Then and Now: Implications for Empirical Research. In Michael Katz and Thomas Sugrue (Eds.), W. E. B. Du Bois, Race, and the City: The Philadelphia Negro and Its Legacy, pp. 154-193. Philadelphia, PA: University of Pennsylvania Press.

Moses, Wilson J. (1993). W. E. B. Du Bois's "The Conservation of Races" and its Context: Idealism, Conservatism and Hero Worship. Massachusetts Review, 34(2): 275-294.

Nagel, Ernest (1979). The Structure of Science: Problems in the Logic of Scientific Explanation. Indianapolis, IN: Hackett Publishing.

Northrop, F. S. C. (1959). The Logic of the Sciences and the Humanities. New York: Meridian Books.

Outlaw, Lucius T., Jr. (2000). W. E. B. Du Bois on the Study of Social Problems. Annals of the American Academy of Political and Social Science, 568(March): 281-297.

Page, Thomas Nelson (1892). A Southern on the Negro Question. North American Review, 154(425): 401-414. 〈http://cdl.library.cornell.edu/cgi-bin/moa/moa-cgi?notisid=ABQ75780154-51) (accessed October 10, 2006).

Phillips, Ulrich Bonnell (1929). American Negro Slavery: A Survey of the Supply, Employment and Control of Negro Labor as Determined by the Plantation Regime. New York: D. Appleton and Company.

Public Broadcasting Service (PBS) (2004). Tavis Smiley Show, Interview with Bill Cosby, May 26. Transcript available at:〈http://www.pbs.org/kcet/tavissmiley/archive/200405/ 20040526_transcript.html (accessed October 10, 2006).

Public Broadcasting Service (PBS) (2005). Tavis Smiley Show, Interview with Michael Eric Dyson, August 3. Transcript available at: 〈http://www.pbs.org/kcet/tavissmiley/archive/ 200508/20050803_transcript.html $\rangle$ (accessed October 10, 2006).

Pulido, Laura (1996). A Critical Review of the Methodology of Environmental Racism Research. Antipode, 28(2): 142-159.

Pulido, Laura, Steve Sidawi, and Robert Vos (1996). An Archaeology of Environmental Racism in Los Angeles. Urban Geography, 17(5): 419-439.

Rampersad, Arnold (1990). The Art and Imagination of W. E. B. Du Bois. New York: Schocken Books.

Reed, Adolph L. (1997). W. E. B. Du Bois and American Political Thought: Fabianism and the Color Line. New York: Oxford University Press.

Richings, G. F. (1902). Evidences of Progress Among Colored People, 8ed. Philadelphia, PA: George S. Ferguson Company.

Riis, Jacob A. (1890). How the Other Half Lives. New York: Charles Scribner's Sons. 〈http:// www.cis.yale.edu/amstud/inforev/riis/title.html $\rangle$ (accessed October 10, 2006).

Riis, Jacob A. (1931 [1901]). The Making of an American. New York: Macmillan Company.

Rudwick, Elliot (1957). W. E. B. Du Bois and the Atlanta University Studies on the Negro. Fournal of Negro Education, 26(4): 466-476.

Schafer, Axel R. (2001). W. E. B. Du Bois, German Social Thought, and the Racial Divide in American Progressivism, 1892-1909. Fournal of American History, 88(3): 925-949.

Shaler, Nathaniel Southgate (1884). The Negro Problem. Atlantic Monthly, 54(325): 696-709. $\langle$ http://cdl.library.cornell.edu/cgi-bin/moa/moa-cgi?notisid=ABK2934-0054-117 (accessed October 10, 2006).

Smith, Roger (1997). The Norton History of the Human Sciences. New York: W.W. Norton and Company.

Society of Friends (1849). A Statistical Inquiry into the Condition of the People of Colour, of the City and Districts of Philadelphia. Philadelphia, PA: Kite and Walton. 〈http://dlxs.library.cornell.edu/ cgi $/ \mathrm{t} /$ text $/$ pageviewer-idx? $\mathrm{c}=$ mayantislavery;idno $=02818204 ; \mathrm{view}=$ image $;$ seq $=1\rangle($ accessed October 10, 2006).

Straton, John Roach (1900). Will Education Solve the Race Problem? North American Review, 170: 785-802.

Taylor, Carol M. (1981). W. E. B. Du Bois's Challenge to Scientific Racism. Fournal of Black Studies, 11(4): 449-460. 
Taylor, Paul (2004). What's the Use of Calling Du Bois a Pragmatist? Metaphilosophy, 35(1-2) : 99-114.

Terman, Lewis Madison (1916). The Measurement of Intelligence; an Explanation of and a Complete Guide for the Use of the Stanford Revision and Extension of the Binet-Simon Intelligence Scale. Boston, MA: Houghton Mifflin Company.

Thomas, W. I. (1904). The Psychology of Race-Prejudice. American fournal of Sociology, 9: 593-611. 〈http://spartan.ac.brocku.ca/ lward/Thomas/Thomas_1904_b.html〉 (accessed October 10, 2006).

U.S. Department of Labor (n.d.). Early Department of Labor Black Studies. 〈http://www.dol.gov/ oasam/programs/history/blackstudieslist.htm $\rangle$ (accessed January 2, 2007).

Warner, Charles Dudley (1902). Education of the Negro. In Charles Dudley Warner, Fashions in Literature, and Other Literary and Social Essays and Addresses. New York: Dodd, Mead and Company. 〈http://www.gutenberg.org/etext/3114〉 (accessed October 10, 2006).

Washington, Booker T. (1896). The Awakening of the Negro. Atlantic Monthly, 78(466): 322-328. 〈http://etext.lib.virginia.edu/etcbin/toccer-new2? id=WasAwak.sgm\&images= images $/$ modeng\&data $=$ texts/english $/$ modeng $/$ parsed $\&$ tag $=$ public $\&$ part $=$ all $\rangle($ accessed October 10, 2006).

Washington, Booker T. (1899 [1976]). The Future of the Race. In Louis R. Harlan and Raymond W. Smock (Eds.), The Booker T. Washington Papers, Open Book Edition, Volume 5: 1899-1900, pp. 299-392. Champaign, IL: University of Illinois Press. 〈http:// www.historycooperative.org/btw/Vol.5/html/R3.html (accessed October 10, 2006).

Washington, Booker T. (1901). Up From Slavery: An Autobiography. Garden City, NY: Doubleday and Company. 〈http://docsouth.unc.edu/washington/washing.html〉 (accessed October 10, 2006).

Weber, Max (1949). The Methodology of the Social Sciences. Edited by Edwards A. Shils and Henry A. Finch. New York: Free Press.

Wells-Barnett, Ida B. (1892). Southern Horrors: Lynch Law in All Its Phases. New York: New York Age Printing. 〈http://www.gutenberg.org/etext/14975〉 (accessed October 10, 2006).

Wells-Barnett, Ida B. (1895). The Red Record: Tabulated Statistics and Alleged Causes of Lynching in the United States. Chicago, IL: Donohue and Henneberry. 〈http://www.gutenberg.org/ etext/14977> (accessed October 10, 2006).

Wells-Barnett, Ida B. (1900). Mob Rule in New Orleans: Robert Charles and His Fight to Death, the Story of His Life, Burning Human Beings Alive, Other Lynching Statistics. 〈http:// www.gutenberg.org/etext/14976> (accessed October 10, 2006).

West, Cornel (1989). The American Evasion of Philosophy: A Genealogy of Pragmatism. Madison, WI: University of Wisconsin Press.

Williams, George W. (1883). History of the Negro Race in America From 1619 to 1880, Two Volumes. New York: G. P. Putnam's Sons.

Williams, Robert W. (1999). Environmental Injustice in America and Its Politics of Scale. Political Geography, 18(1): 49-74.

Williams, Robert W. (2005). Getting to the Heart of Environmental Injustice: Social Science and Its Boundaries. Theory and Science, 6(1). 〈http://theoryandscience.icaap.org/content/ vol6.1/williams.html $\rangle$ (accessed October 10, 2006).

Williamson, Thames Ross (1922). Problems in American Democracy. Boston, MA: D. C. Heath and Company. 〈http://www.gutenberg.org/etext/6460〉 (accessed October 10, 2006).

Wilson, William Julius (1980). The Declining Significance of Race: Blacks and Changing American Institutions, 2ed. Chicago, IL: University of Chicago Press.

Windelband, Wilhelm (1924 [1980]). History and Natural Science. History and Theory, 19(2): $165-168$.

Work, Monroe Nathan (Ed.) (1931). The Negro Yearbook: An Annual Encyclopedia of the Negro, 1931-1932. Tuskegee Institute, AL: Negro Year Book Publishing Company.

Wortham, Robert A. (2005). Introduction to the Sociology of W. E. B. Du Bois. Sociation Today, 3(1). 〈http://www.ncsociology.org/sociationtoday/v31/atlanta.htm〉 (accessed October 10, 2006).

Wright, Earl, II (2002a). The Atlanta Sociological Laboratory 1896-1924: A Historical Account of the First American School of Sociology. Western Fournal of Black Studies, 26(3): $165-174$.

Wright, Earl, II (2002b). Why Black People Tend to Shout! An Earnest Attempt to Explain the Sociological Negation of the Atlanta Sociological Laboratory Despite its Possible Unpleasantness. Sociological Spectrum, 22(3): 335-361. 


\section{Robert W. Williams}

Wright, Earl, II (2005). W. E. B. Du Bois and the Atlanta Sociological Laboratory. Sociation Today, 3(1). 〈http://www.ncsociology.org/sociationtoday/v31/wright.htm〉 (accessed October 10, 2006).

Wright, Richard R., Jr. (1903). The Negroes of Xenia, Ohio: A Social Study. Bulletin of the U.S. Bureau of Labor, 48(September): 1006-1044. 〈http://dbs.ohiohistory.org/africanam/ det.cfm? ID = 1106 (accessed October 10, 2006).

Wright, Richard R., Jr. (1912). The Negro in Pennsylvania: A Study in Economic History. Philadelphia, PA: A.M.E. Book Concern Printers.

Young, Alford A., Jr. and Donald R. Deskins, Jr. (2001). Early Traditions Of African-American Sociological Thought. Annual Review of Sociology, 27: 445-477.

Zamir, Shamoon (1995). Dark Voices: W. E. B. Du Bois and American Thought, 1888-1903. Chicago, IL: University of Chicago Press.

Zuberi, Tukufu (2004). W. E. B. Du Bois's Sociology: The Philadelphia Negro and Social Science. Annals of the American Academy of Political and Social Science, 595: 146-156.

Zuckerman, Phil (2002). The Sociology of Religion of W. E. B. Du Bois. Sociology of Religion, 63(2): 239-253.

Zuckerman, Phil (2004). The Social Theory of W. E. B. Du Bois: An Introduction. In Phil Zuckerman (Ed.), The Social Theory of W. E. B. Du Bois, pp. 1-18. Thousand Oaks, CA: Pine Forge Press. 